Alfarama Journal of Basic \& Applied Sciences

Faculty of Science Port Said University https://ajbas.journals.ekb.eg

ajbas@sci.psu.edu.eg

http://sci.psu.edu.eg/en/

January 2021, Volume 2, Issue 1

DOI: $\underline{10.21608 / a j b a s .2020 .37472 .1026}$

Submitted: 28-07-2020

Accepted: $30-08-2020$

Pages: 70-80

\title{
Role of Drenched Barley in Improving Cerebral Structure and Function in Hypercholesterolemic Albino Rat Dam
}

\author{
Zahraa A. Greash ${ }^{1, *}$, Osama A. Abbas ${ }^{1}$, Hassan I. El-Sayyad ${ }^{2}$ \\ ${ }^{1}$ Zoology Department, Faculty of Science, Port Said Univ., Egypt. \\ ${ }^{2}$ Zoology Department, Faculty of Science, Mansoura Univ., Egypt \\ * Corresponding author: drz.g2009@ yahoo.com.
}

\begin{abstract}
High cholesterol diet was responsible for metabolic disease development that considers one of the public health problems. However, there is a little information about the impact of barley supplementation on hypercholesterolemia associated cerebral damage. Sixty virgin female albino rats (Rattus norvegicus) weighing $100 \mathrm{~g}$ body weight were used and categorized into four groups (control, barley, a hypercholesterolemic diet with/without barley). The hypercholesterolemic females ingested a high cholesterol diet (3\% cholesterol) for four months before conception and throughout gestation and lactation period. Dams of the studied groups were sacrificed at the third weekpostpartum. Cerebrum was removed and processed for histopathological, proliferating cell nuclear antigen (PCNA) and glial fibrillary acidic protein (GFAP) immunohistochemical investigations. Assessments of antioxidants, lipid peroxidation, neurotransmitters and interleukins levels were carried out. The present findings showed that the ingestion of drenched barley to mothers fed on a high cholesterol diet decreased lipid peroxidation, and decreased inflammatory markers coincides with increased assayed both antioxidant enzymes and neurotransmitters. These were reflected in the histological picture as well as increased proliferating cell nuclear antigen and decreased glial fibrillary acidic protein immunohistochemically. The authors concluded that drenched barley contains essential nutrients and flavonoids which increased the antioxidant defense facilitated to improve the drastic damage induced by a high cholesterol diet on cerebral neurons and restored their functional activity.

Keywords
\end{abstract}

antioxidants, barley, cerebrum, cholesterol, neurotransmitters.

\section{INTRODUCTION}

High cholesterol intake is closely linked to atherosclerosis, hypertension, obesity, diabetes and cancer [1-4]. The elevated dietary intake of the oxidized-cholesterol for 14 weeks could affect the memory that was positively associated with increased oxidative stress and reduced brain tissues coenzyme Q10 [5]. This is also correlated with the altering of the cerebral microvasculature and increase cerebral inflammation [6] leading to deposition of amyloid- $\beta$ (A $\beta)$ and the development of Alzheimer's disease [7]. High cholesterol diet associated with accumulation of $A \beta$ resulted in reducing the cholesterol homeostasis that causes 
neurodegeneration of cerebral neurons [8]. Studies indicated that not only the cholesterol content but also its distribution within neurons, involved in $A \beta$ biogenesis [9] and may harm microglia-derived exosomes resulting in impairment of cognition and synaptic plasticity [10].

Barley contains numerous vital nutrients such as antioxidants and phenolic compounds [11,12]. The phenolic compounds attain $0.2-0.4 \%$ such as benzoic and cinnamic acid derivates, flavonoids, chalcones, tannins, quinones, proanthocyanidins and amino phenolic compounds [13,14].

Also,phenolic acids, flavonoids, lignans, tocols, phytosterols, and folate are included which possessed potent antioxidant, anti-proliferative, and cholesterol-lowering activities [15]. $\beta$-glucans exhibited hypolipidemia especially of cholesterol and triglyceride levels in an animal model [16] and humans [17-19] by increasing their transport towards the large intestine [20] and reduces cholesterol absorption, and its excretion [21] .

The present work was aimed to demonstrate the therapeutic potential of drenched barley on the cerebrum structure and function of rat dam ingested diet rich in cholesterol.

\section{MATERIALS AND METHODS}

\subsection{Preparation of a high cholesterol diet:}

The diet is composed of 3\% cholesterol, $10 \%$ animal fat, $2 \%$ cholic acid and $2 \%$ thiouracil and the rest is standard diet formula [22]. Rats were fed for 4 months before conception and throughout pregnancy as well as lactation period.

\subsection{Diets containing drenched barley:}

A standard diet containing all the nutrients requirements were prepared and used for the control individuals. Barley was soaked for three days prior to mixing with either a standard diet or hypercholesterolemic diet at a ratio of $20 \%$ (Table 1). Both control and hypercholesterolemic dams were fed on this dietary regimen during gestation and lactation period. The hypercholesterolemic group was fed on a diet containing drenched barley after 6 weeks of continuous feeding on a high cholesterol diet prior to conception and throughout gestation as well as lactation periods.

\subsection{Experimental animals:}

This laboratory work was carried out according to the requirements of the National Institute of Health and the Egyptian Committee of Bioethics and use of Laboratory Animals. Sixty virgin female and twenty adult male albino rats (Rattus norvegicus) weighing about $100 \mathrm{~g}$ body weight were brought from Helwan Breeding Farm, Ministry of Health, Egypt. They were adapted and housed in a well-ventilated lab with 12 light and dark hours. Free access to food and water was provided ad libitum. The matting was carried out and pregnancy was determined by observing sperm in vaginal smears the next morning and zero date of gestation was recorded. The pregnant were divided into 4 groups $(n=15)$; control $(C)$, barley (B), high cholesterol diet $(\mathrm{H})(3 \%)$ and/or drenched barley (20\%) feeding $(\mathrm{H}+\mathrm{B})$ group. Dams of the studied groups were sacrificed at the $3 \mathrm{rd}$ week postpartum and their cerebra were dissected and investigated as follows:

\subsection{Histological investigation:}

The cerebra of the studied groups were separated and fixed immediately in 10\% phosphate-buffered formalin ( $\mathrm{pH}$ 7.4), dehydrated in ethyl alcohol ascending series, cleared in xylene then mounted in molten paraplast at $58-62{ }^{\circ} \mathrm{C}$. Five $\mu \mathrm{m}$ histological sections were cut, stained with Hematoxylin\& eosin [23], and examined under a bright field light microscope. 
Table (1): Percentage of dietary constituents in the different studied groups:

\begin{tabular}{|c|c|c|c|c|}
\hline$\overbrace{\text { Ingredients }(\%)}^{\text {Groups }}$ & Control & $\begin{array}{c}\text { Barley } \\
\text { diet }\end{array}$ & $\begin{array}{c}\text { Hypercholesterolemic } \\
\text { diet }\end{array}$ & $\begin{array}{c}\text { Hypercholesterolemic } \\
\text { diet \& barley }\end{array}$ \\
\hline Crude protein & 16 & 16 & 14 & 14 \\
\hline Carbohydrates & 15 & 15 & 5 & 5 \\
\hline Animal fat & 4 & 4 & 10 & 10 \\
\hline Cellulose & 13 & - & 13 & - \\
\hline Barley & - & 20 & - & 20 \\
\hline Cholesterol & - & - & 3 & 3 \\
\hline Casein & 10 & 3 & 15 & 8 \\
\hline Choline bitartrate & 1 & 1 & 1 & 1 \\
\hline Cholic acid & - & - & 2 & 2 \\
\hline Thiouracil & - & - & 2 & 2 \\
\hline Vitamins & 2.5 & 2.5 & 2.5 & 2.5 \\
\hline Minerals & 2.5 & 2.5 & 2.5 & 2.5 \\
\hline Corn starch & 15 & 15 & 15 & 15 \\
\hline Sucrose & 10 & 10 & 5 & 5 \\
\hline Moisture & 7 & 7 & 7 & 7 \\
\hline Ash & 4 & 4 & 3 & 3 \\
\hline
\end{tabular}

\subsection{Immunohistochemistry for PCNA, GFAP, and $\beta$-amyloid:}

Five $\mu \mathrm{m}$ histological sections of formalin-fixed, paraffin-embedded cerebrum tissue were placed on polylysine-coated glass slides. Tissue sections were deparaffinized in xylene after overnight packing at $65^{\circ} \mathrm{C}$ and rehydrated in alcohol descending grades. Endogenous peroxidase activity was removed by incubation of tissue sections in $3 \% \mathrm{H}_{2} \mathrm{O}_{2}$ for 10 minutes at room temperature. The tissue sections were placed in digested media composed of $0.05 \%$ trypsin $(\mathrm{pH} 7.8)$ for 15 minutes at $37^{\circ} \mathrm{C}$ and incubated with the primary antibody of Glial fibrillary acidic protein GFAP, the primary antibody against proliferating cell nuclear antigen PCNA and amyloid- $\beta$ (DAKO, clone MIB5, 1:50, mouse) at 1:50 overnight at $4^{\circ} \mathrm{C}$. After washing, the slides were incubated at room temperature with secondary biotin linked anti-mouse antibody for 50 minutes, and with the streptavidin-peroxidase complex for 50 minutes, then washed and incubated with developing solution (diaminobenzidine-hydrogen peroxide; DAKO), and counterstained with hematoxylin. As a result of the immune reaction, brown cytoplasmic or nuclear labeling counterstained with hematoxylin was visualized. Incubated sections with $1 \%$ nonimmune serum phosphate buffer solution (PBS), the solution used as negative controls. The sections were examined by using a bright-field light Olympus microscope with a digital canon camera.

\subsection{Biochemical assays:}

The cerebrum tissue was separated, homogenized in $10 \%$ ice-cold $2.5 \mathrm{mM}$-tris buffer $(\mathrm{pH} 7.5$ ) and centrifuged at 14000.x-g for 15 minutes at $4{ }^{\circ} \mathrm{C}$ and the supernatant was kept in a deep freeze for the following biochemical investigations:

\subsubsection{Determination of superoxide dismutase and glutathione-S-transferase activities:}

Superoxide dismutase (SOD) was determined by using the BioVision Kit (BioVision Research Products, 980 Linda Vista Avenue, Mountain View, CA 94043, USA, Catalog. No. K335-100) by the reduction of the superoxides with nitro blue tetrazolium to blue color of formazan and measured at $560 \mathrm{~nm}$ [24]. Meanwhile, glutathione-S-reductase (GSH) was determined by using the BioVision Kit (BioVision Incorporated, $155 \mathrm{~S}$. Milpitas Boulevard, Milpitas, CA 95035, USA, Catalog. No. K264-100) by precipitation of protein using tungstate-sulfuric acid solution followed by reaction with 5,5 dithiobis-25-nitrobenzoic acid (DNTB) and formation of the yellow color and read at $412 \mathrm{~nm}$ [25].

\subsubsection{Determination of lipid peroxidation end product as malondialdehyde:}

It is determined by using the BioVision Kit (BioVision Incorporated, 155 S. Milpitas Boulevard, Milpitas, CA 95035, USA, Catalog. No. K739-100) by adding $500 \mu 1$ of the thiobarbituric acid reagent to the sample supernatant, boiling in a water bath then coaling, the reddish-pink color was developed and measured at 534 nm [26]. 


\subsubsection{Determination of 8-hydroxy-2-deoxy guanosine (8-hdG):}

It is determined by using the Bioxytech-ELISA Kit (OXIS Health Products, Portland, OR, USA, Catalog. No. KOG-200S/E) and the reaction were measured at $450 \mathrm{~nm} \mathrm{[27].}$

\subsubsection{Assessments of Caspase-3:}

It is determined by using a Stress-gen colorimetric kit (catalog. No. 907-013). The cleavage of the peptide was measured spectrophotometrically at a wavelength of $405 \mathrm{~nm}$.

\subsubsection{Determination of dopamine (DA), serotonin (5-HT), and $\gamma$-aminobutyric acid (GABA) neurotransmitters:}

High-performance liquid chromatography (HPLC) with the precolumn PTC derivatization technique was used to measure $\gamma$-amino-butyric acid, dopamine, and serotonin [28]. The assay conditions were carried out at $46{ }^{\circ} \mathrm{C}, 254 \mathrm{~nm}$, and flow rate: $1 \mathrm{ml} / \mathrm{min}$. Dopamine, and serotonin were assayed on bases of removal of trace elements and lipid from the tested samples by solid-phase extraction CHROMABOND column NH2 phase Cat. No. 730031 and injected directly into an AQUA column $15054.6 \mathrm{~mm}$ (Phenomenex, USA) [29].

\subsubsection{Determination of interleukin:}

It is estimated by using Enzyme-linked Immunosorbent Assay Kit of Cloud-Clone Corp, Cat. No. SEA079Ra for interleukin 6, Cat. No. SEA056Ra for interleukin 10 and Cat. No.SEA063Ra for interleukin 17.

\subsubsection{Assessments of phosphatidylethanolamine, sphingomyelin, and polyenylphosphatidylcholine:}

Phosphatidylethanolamine (PE), Sphingomyelin (SM), and polyenylphosphatidylcholine (PPC) were estimated in cerebrum tissues according to Parker and Peterson method [30].

\subsubsection{Determination of homocysteine, and amyloid-B:}

It is estimated by using Enzyme-linked Immunosorbent Assay Kit of Cloud-Clone Corp, Homocysteine (Hcy, cataloge. no. CSB-E13376r) and amyloid-B42 (Ab1-42, cataloge. no. CEA946Ra).

\subsubsection{Determination of iron concentration:}

Samples of the studied groups were digested by $1 \mathrm{~mL}$ of nitric acid at highest purity and diluted with $4 \mathrm{~mL}$ bi-distilled water and their iron concentration was measured by atomic absorption spectrometry [31].

\subsection{Statistical analysis:}

The statistical analysis was performed with one-way post-hoc analysis of variance (ANOVA) using SPSS (version 15) software package for Windows (SPSS Inc., Chicago, IL, USA). The data were presented as a mean \pm standard error $(\mathrm{SE})$ and significance were defined as $(\mathrm{p}<0.05)$ and highly significant when $(\mathrm{p}<$ $0.01)$.

\section{RESULTS AND DISCUSSION}

The present study manifested abnormal structural organization of cerebral tissues in rat dams with high dietary intake of cholesterol. The histopathological abnormalities clarified by detecting inflammation of the neuropil characterized by dense aggregation of microglia cells in both the outer granular and polymorphic layers. It was associated with hyalinization and degeneration of neuropil. Many intra- and extracytoplasmic vacuoles of varying sizes were observed. The pyramidal cells that appeared within the outer pyramidal layer were shrunken with loss of their processes and had pericellular halos. The neuropil inclosing the neurons showed vacuolation of varying sizes. Also, many of the neurons had pericellular halos and showed vacuolated background (Fig. 1). These observations parallel with increasing the inflammatory markers of caspase-3, interleukin-6, and -17 in the high cholesterol diet mother rats (Table 2, 3). Different results suggest increased IL-6 and caspase-1 expression in the brain post-high cholesterol diet [32] and hypothalamus post-high fat diet [33]. Neuronal death in a variety of neurodegenerative diseases, including 
Alzheimer's disease (AD), has been associated with deregulated caspase activation [34] associated with disease onset occurred earlier than the induction of neuronal apoptosis [35].

Oxidative stress plays an important role in the pathogenesis of many diseases. These were illustrated and confirmed in this study by increased 8-hydroxyguanosine level and MDA concentration parallel with decreased glutathione-s-reductase and superoxide dismutase activities (Table 2). The relation between hypercholesterolemia and oxidative stress in causing endothelial dysfunction in cerebral arterioles even with atherosclerotic lesions absence was recorded [36], there are neuropathological changes occur during the feeding of hypercholesterolemic diet via increased the oxidant malondialdehyde production in the hippocampus [37], highlighting the link between oxidative stress, memory impairment [5], cognition disorders [38] and Alzheimer's disease (AD) towards the $\mathrm{A} \beta$ peptide consequences and surrounding molecules in terms of oxidative damage [39].

High cholesterol diet causing damage to the brain by enhancing inflammatory and oxidative reactions which induce neuronal apoptosis illustrating by increasing iron and homocysteine concentrations (Table 3), that led to neurodegenerative diseases, such as Alzheimer's disease, stroke and vascular dementia [40, 41]. As well as, a high cholesterol diet causes marked impairment in brain functions that have been evaluated by depleting dopamine, serotonin, and $\gamma$-aminobutyric acid neurotransmitters (Table 3), which is consistent with [42] recorded dopamine, and serotonin depletion in the striatum and cortex of hypercholesterolemic mice, respectively. Lacking serotonin may predispose individuals to impulse aggression [43]. Also, depletion of GABA contributes to ongoing neuronal excitability and possibly to neuronal death [44] and increased the damage observed in hyperglycemic stroke [45].

The brain is a rich organ in phospholipids [46], that involve in transmission and relay signals from the membrane to intracellular compartments or other cells, changes in its levels may contribute to different pathogenic processes, such as in Alzheimer's disease [47], depression and anxiety disorders [48]. The assayed phospholipid fractions levels were markedly decreased in the brain of high cholesterol diet (Table 2), similar findings reported in the hippocampus in Alzheimer's disease [49] and the brain of western diet mice [50].

The presented findings observed the dietary of high cholesterol diet manifested up-regulation of amyloid- $\beta$ (Table 3), that agree with the neuropathological analysis indicated that the hypercholesterolemic diet significantly increased beta-amyloid load by elevating both deposit number and size [51], enhanced the cortical beta-amyloid which resemble an AD-like pathology [52, 53], induce neuronal, astrocytic death [54], synapse loss and memory impairment [55].

In the cerebral of a mother fed on a high cholesterol diet, there was comparative reductions of PCNA immunohistochemical reaction and overexpression of both GFAP and $\beta$-amyloid immunohistochemical reaction (Fig. 2) that reflect the neurodegenerative states and metabolic abnormalities. These agree with [56] indicated the effect of hypercholesterolemia on the blood-brain barrier (BBB) integrity through increasing the expression of tight junction proteins and Glial fibrillary acidic protein (GFAP). Also, recorded increased in the beta immunostained plaque-like deposits in mice fed the HFHC diet [57].

On the other hand, barley revealed an improvement in the assayed cerebral biochemical analysis (Table 2, 3) when added to the hypercholesterolemic diet. These results were parallel with apparent amelioration of the cerebral histopathological (Fig. 1) and immunohistochemical pictures (Fig. 2) and agree with numerous studies that recorded the effect of whole grains such as oats and barley in lowering blood cholesterol due to its high content of soluble fiber [58-60]. Barley exhibited several vital components including phenolic, flavonoids [11, 12, 15] and phytochemicals compounds with strong antioxidant, antiproliferative and cholesterol-lowering efficiency, so it has the ability in reducing certain diseases [15], such as total stroke by increasing the HDL cholesterol medium and small particle [61]. As well as, daily oral administration of talbina increases the brain content of dopamine (DA), serotonin (5-HT) and gamma-aminobutyric acid $(\mathrm{GABA})$ in male albino rats [62]. 
Table (2): Cerebral activities of GSH and SOD, contents of phospholipids, MDA, Casp3, 8-HdG and Iron of mother fed on a high cholesterol diet with or without barley-supplementation:

\begin{tabular}{|c|c|c|c|c|c|c|c|c|c|}
\hline Paran & GSH & SOD & Phos & pholipids ( & ing $/ g$ ) & $\mathrm{MDA}$ & Casp3 & 8-HdG & Iron \\
\hline Groups & & & PE & SM & PPC & & & & \\
\hline C & $89.4 \pm 4.5$ & $39.7 \pm 2.1$ & $1.39 \pm 0.2$ & $3.42 \pm 0.5$ & $4.17 \pm 0.6$ & $15.39 \pm 0.8$ & $5.14 \pm 0.5$ & $6.98 \pm 0.3$ & $29.7 \pm 1.5$ \\
\hline B & $89.6 \pm 4.5$ & $39.9 \pm 2.1$ & $1.42 \pm 0.2$ & $3.78 \pm 0.6$ & $4.46 \pm 0.7$ & $14.85 \pm 0.7$ & $4.53 \pm 0.5$ & $6.74 \pm 0.4$ & $29.6 \pm 1.5$ \\
\hline H & $48,1 \pm 7.1^{*}$ & $28.6 \pm 1.7^{*}$ & $0.85 \pm 0.1^{*}$ & $2.37 \pm 0.3$ & $3.34 \pm 0.5^{*}$ & $24.12 \pm 2.1^{*}$ & $8.4 \pm 0.4^{*}$ & $8.69 \pm 0.4$ & $32.6 \pm 1.6$ \\
\hline HB & $74.7 \pm 3.7$ & $34.9 \pm 1.9$ & $1.28 \pm 0.2$ & $2.92 \pm 0.4$ & $3.76 \pm 0.6$ & $19.02 \pm 0.9$ & $6.98 \pm 0.3^{*}$ & $7.53 \pm 0.4$ & $30.8 \pm 1.5$ \\
\hline
\end{tabular}

Each result represents the mean $\pm \mathrm{SE}$ of $\mathrm{n}=5$. Star means significant at $\mathrm{P}<0.05$ comparing with the control group. Abbreviations; B, barley; C, control; Casp3, caspase-3; GSH, glutathione-s-reductase; H, hypercholesterolemic diet; HB, hypercholesterolemic diet containing barley; 8-HdG, 8hydroxydeoxyguanosine; MDA, malondialdehyde; PE, phosphatidylethanolamine; PPC, polyenylphosphatidylcholine; SM, sphingomyelin; SOD, superoxide dismutase.

Table (3): Cerebral contents of DA, 5-HT, GABA, Amyloid $\beta$, Homocystine, IL6, IL17 and IL10 of rat dam fed on a high cholesterol diet with or without barley-supplementation:

\begin{tabular}{|c|c|c|c|c|c|c|c|c|}
\hline Parar & $\begin{array}{c}\text { DA } \\
\text { (nggm) }\end{array}$ & $\begin{array}{c}\text { 5-HT } \\
\text { (nggm) }\end{array}$ & $\begin{array}{l}\text { GABA } \\
\text { (nggin) }\end{array}$ & $\begin{array}{c}\text { Amyloid } \beta \\
\text { (pgigm) }\end{array}$ & $\begin{array}{c}\mathrm{HCY} \\
\text { (nmol gm) }\end{array}$ & $\underset{\text { (pggm) }}{\text { IL6 }}$ & $\begin{array}{c}\text { IL17 } \\
\text { (pgigm) }\end{array}$ & $\begin{array}{l}\text { IL10 } \\
\text { (pg gin) }\end{array}$ \\
\hline C & & & & & & & & $11.6 \pm 0.6$ \\
\hline B & $51.2 \pm 2.6$ & $92.9 \pm 4.6$ & $175.9 \pm 8.8$ & $293 \pm 14.6$ & $11.3 \pm 1.1$ & $181.3 \pm 9.1$ & $162.6 \pm 8.1$ & $11.8 \pm 0.6$ \\
\hline H & $31.8 \pm 1.7^{*}$ & $74.1 \pm 3.7^{*}$ & $162.6 \pm 8.1$ & $430.3 \pm 21.5^{*}$ & $18.5 \pm 1.8^{*}$ & $245.9 \pm 12.3^{*}$ & $191.3 \pm 9.6^{* *}$ & $6.1 \pm 0.3^{* *}$ \\
\hline $\mathrm{HB}$ & $36.5 \pm 1.8^{*}$ & $78.3 \pm 3.9^{*}$ & $169.9 \pm 8.5$ & $314.3 \pm 15.7$ & $14.6 \pm 1.5$ & $198.4 \pm 9.9$ & $176.2 \pm 8.8^{*}$ & $7.7 \pm 0.4^{*}$ \\
\hline
\end{tabular}

Each result represents the mean $\pm \mathrm{SE}$ of $\mathrm{n}=5$. One star means significant at $\mathrm{P}<0.05$; Double stars mean high significant at $\mathrm{P}<0.01$ comparing with the control group. Abbreviations; B, barley; C, control; DA, dopamine; GABA, $\gamma$-aminobutyric acid; $\mathrm{H}$, hypercholesterolemic diet; $\mathrm{HB}$, hypercholesterolemic diet containing barley; HCY, Homocystine; 5-HT, serotonin; IL6, interleukin 6; IL10, interleukin 10; IL17, interleukin 17. 


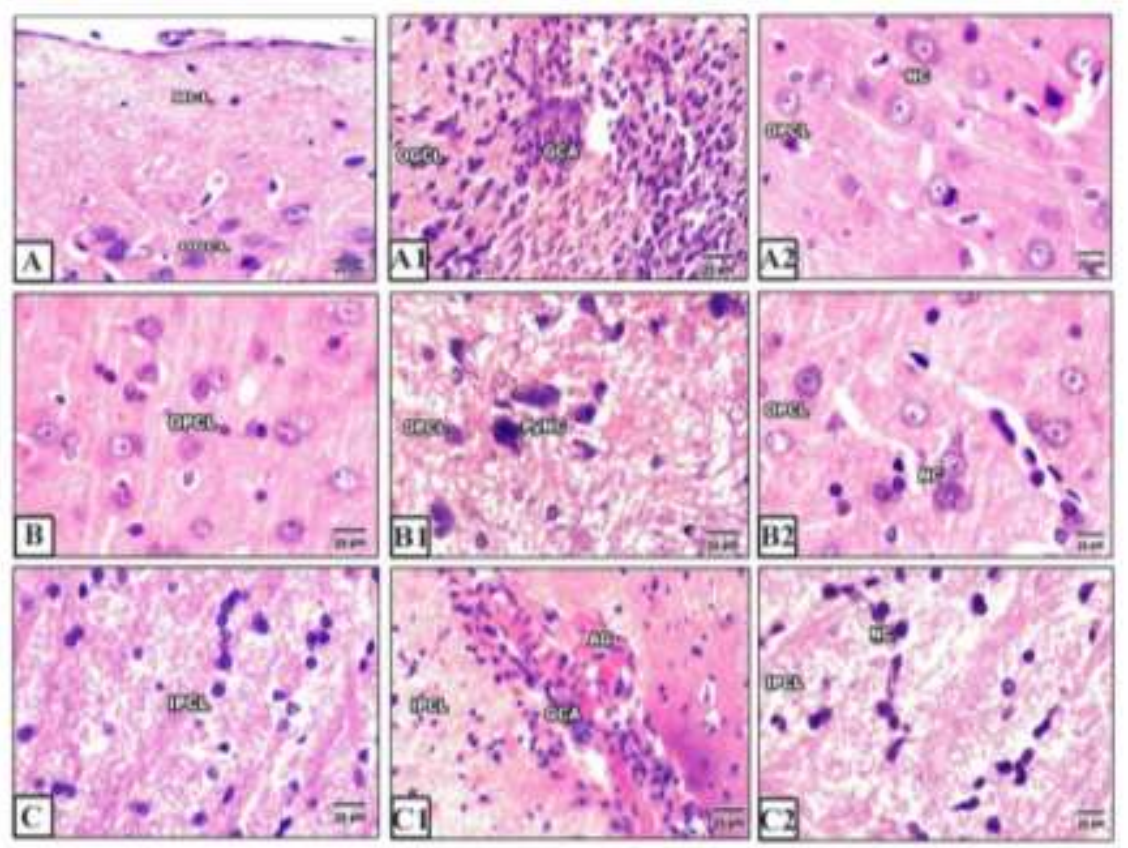

Fig. (1): Photomicrograph of sagittal histological section of cerebral cortex of rat dam. (A-C) control dam showing normal pattern of cerebral cell layers. (A1-C1) dam fed on high cholesterol diet showing cerebral histopathological abnormalities in the form of pyknotic neuronal cells (PyNC) in the outer pyramidal cell layer and gliosis cell accumulation (GCA) in the outer granular cell layer and inner pyramidal cell layer with accumulation of gliosis cells (AG). (A2-C2) dam fed on high cholesterol diet with barley showing marked improvement in the cerebral layers. H\&E. Abbreviations; IPCL, inner pyramidal cell layer; MCL, molecular cell layer; NC, normal cell; OGCL, outer granular cell layer; OPCL, outer pyramidal cell layer.
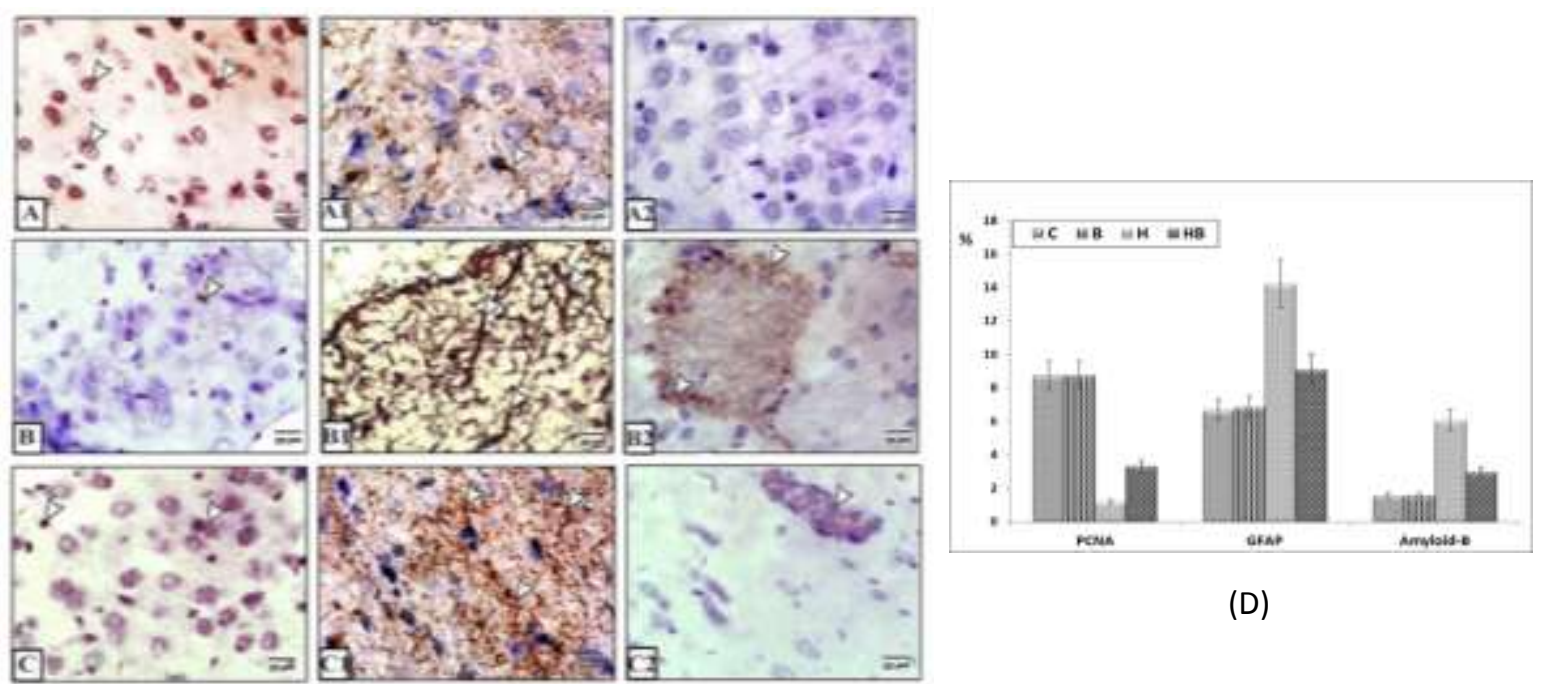

(D)

Fig. (2): Photomicrograph of formalin-fixed, paraffin-embedded cerebral cortex of rat dam immunohistochemically stained with PCNA antibody (A-C), GFAP antibody (A1-C1) and amyloid- $\beta$ antibody (A2-C2). A, A1\& A2, control dam showing increased PCNA expression, decreased GFAP expression and absence of amyloid- $\beta$ expression in neuronal cells, respectively. B, B1\& B2, dam fed on a high cholesterol diet showing decreased expression of PCNA, increased GFAP and amyloid- $\beta$ expressions, respectively. C, C1\& $\mathrm{C} 2$, dam fed on a high cholesterol diet containing barley showing moderate expressions of PCNA, GFAP and amyloid- $\beta$, respectively. Arrowheads indicate the positive immunoreaction. D. Chart illustrating image analysis of immunohistochemical reaction of PCNA, GFAP and amyloid- $\beta$ of cerebral cortex. Abbreviations; B, barley supplemented dam; $\mathrm{C}$, control dam; $\mathrm{H}$, dam fed on a high cholesterol diet; HB, dam fed on high cholesterol diet containing barley. Note, decreased PCNA, increased GFAP and amyloid- $\beta$ average image analysis in hypercholesterolemic group compared to the other experimental groups. 


\section{CONCLUSION}

The present research concluded that dam fed on high cholesterol diet is involved in oxidative stress and inflammatory reactions associated with neurodegeneration of the cerebral cortex. The decrease of inflammatory and apoptotic markers was achieved after consumption of drenched barley may be due to its prospected high antioxidant activity that scavenges the free radicals and consequently restores the cerebral structure and function.

\section{REFERENCES}

[1] AHMADIZAR, F., SOUVEREIN, P., DE BOER, A. AND MAITLAND-VAN DER ZEE, A.H. Under-treatment of hypertension and hypercholesterolemia in children and adolescents with type 1 diabetes- Long term follow-up on time trends in the occurrence of cardiovascular disease, risk factors and medications use. Br. J. Clin. Pharmacol., 84(4),776-785, 2018.

[2] BAEK, A.E., YU, Y.A., HE, S., WARDELL, S.E., CHANG, C.Y., KWON, S., PILLAI, R.V., MCDOWELL, H.B., THOMPSON, J.W., DUBOIS, L.G., SULLIVAN, P.M., KEMPER, J.K., GUNN, M.D., MCDONNELL, D.P. AND NELSON, E.R. The cholesterol metabolite 27 hydroxycholesterol facilitates breast cancer metastasis through its actions on immune cells. Nat. Commun., 8(1), 864, 2017.

[3] CESKA, R. Hyperlipoprotienemias and (not only) atherosclerosis, fragments from history and present. Cas. Lek. Cesk., 156(6), 303-307, 2017.

[4] CZUBKOWSKI, P., WIERZBICKA, A., PAWŁOWSKA, J., JANKOWSKA, I. AND SOCHA, P. Obesity, lipid profiles and oxidative stress in children after liver transplantation. Acta. Biochim. Pol., 64(4), 661-665, 2017.

[5] KHORRAMI, A., GHANBARZADEH, S., MAHMOUDI, J., NAYEBI, A.M., MALEKIDIZAJI, N. AND GARJANI, A. Investigation of the Memory Impairment in Rats Fed with Oxidized-Cholesterol-Rich Diet Employing Passive Avoidance Test. Drug Res. (Stuttg), 65(5), 231-237, 2015.

[6] RODRIGUES, S.F., ALMEIDA-PAULA, L.D. AND GRANGER, D.N. Synergistic effects of high blood cholesterol and hypertension on leukocyte and platelet recruitment in the cerebral microcirculation. Hypertension, 63(4), 747-752, 2014.

[7] REED, B., VILlENEUVE, S., MACK, W., DECARLI, C., CHUI, H.C. AND JAGUST, W. Associations between serum cholesterol levels and cerebral amyloidosis. JAMA Neurol., 71(2), 195-200, 2014.

[8] YAO, Z.X. AND PAPADOPOULOS, V. Function of beta-amyloid in cholesterol transport, a lead to neurotoxicity. FASEB J., 16(12), 1677-1679, 2002.

[9] PUGLIELli, L., TANZI, R.E. AND KOVACS, D.M. Alzheimer's disease, the cholesterol connection. Nat. Neurosci., 6(4), 345-351, 2003.

[10] VINUESA, A., BENTIVEGNA, M., CALFA, G., FIliPEllo, F., POMIliO, C., BONAVENTURA, M.M., LUX-LANTOS, V., MATZKIN, M.E., GREGOSA, A., PRESA, J., MATTEOLI, M., BEAUQUIS, J. AND SARAVIA, F. EARLY Exposure to a High-Fat Diet Impacts on Hippocampal Plasticity, Implication of Microglia-Derived Exosome-like Extracellular Vesicles. Mol. Neurobiol., 56(7), 5075-5094, 2019.

[11] BARTŁOMIEJ, S., JUSTYNA, R.K. AND EWA, N. Bioactive compounds in cereal grains occurrence, structure, technological significance and nutritional benefits - a review. Food Sci Technol Int., 18(6), 559-568, 2012.

[12] GAMEL, T.H., ABDEL-AAL, E.M. Phenolic acid antioxidant properties of wholegrain and pearling fractions. Agr. Food Sci., 21, 118-131, 2012.

[13] DVORAKOVA, M., GUIDO, L.F., DOSTÁLEK, P., SKULILOVÁ, Z., MOREIRA, M.M. AND BARROS, A.A. Antioxidant properties of free, soluble ester and insoluble-bound phenolic 
compounds in different barley varieties and corresponding malts. J. Inst. Brew., 114, 27-33, 2008.

[14] CARVALHO, D.O., CURTO, A.F. AND GUIDO, L.F. Determination of Phenolic Content in Different Barley Varieties and Corresponding Malts by Liquid Chromatography-diode Array Detection-Electrospray Ionization Tandem Mass Spectrometry. Antioxidants (Basel), 4(3), 563576, 2015.

[15] IDEHEN, E., TANG, Y. AND SANG, S. Bioactive phytochemicals in barley. J. Food Drug Anal., 25(1), 148-161, 2017.

[16] KALRA, S. AND JOOD, S. Effect of Dietary Barley $\beta$-Glucan on Cholesterol and Lipoprotein Fractions in Rat. Journal of Cereal Science, 31(2), 141-145, 2000.

[17] WILSON, T.A., NICOLOSI, R.J., DELANEY, B., CHADWELL, K., MOOLCHANDANI, V., KOTYLA, AND ET AL Reduced and high molecular weight barley beta-glucans decrease plasma total and non-HDL-cholesterol in hypercholesterolemic Syrian golden hamsters. J. Nutr.,134(10), 2617-2622, 2004.

[18] ABUMWEIS, S.S, JEW, S. AND AMES, N.P. $\beta$-glucan from barley and its lipid-lowering capacity, a meta-analysis of randomized, controlled trials. Eur. J. Clin. Nutr., 64(12), 1472-1480, 2010.

[19] MCRORIE, J.W. AND MCKEOWN, N.M. Understanding the Physics of Functional Fibers in the Gastrointestinal Tract, An Evidence-Based Approach to Resolving Enduring Misconceptions about Insoluble and Soluble Fiber. J. Acad. Nutr. Diet., 117(2), 251-264, 2017.

[20] CHEN, J. AND HUANG, X.F. The effects of diets enriched in beta- glucans on blood lipoprotein concentrations. J. Clin. Lipidol., 3(3), 154-158, 2009.

[21] NWACHUKWU, I.D., DEVASSY, J.G., ALUKO, R.E. AND JONES, P.J. Cholesterol-lowering properties of oat $\beta$-glucan and the promotion of cardiovascular health, did Health Canada make the right call?. Appl. Physiol. Nutr. Metab.,40(6), 535-542, 2015.

[22] ENKHMAA, B., SHIWAKU, K., ANUURAD, E., NOGI, A., KITAJIMA, K., YAMASAKI, M., OYUNSUREN, T. AND YAMANE, Y. Prevalence of the metabolic syndrome using the Third Report of the National Cholesterol Educational Program Expert Panel on Detection, Evaluation, and Treatment of High Blood Cholesterol in Adults (ATP III) and the modified ATP III definitions for Japanese and Mongolians. Clin. Chim. Acta., 352(1-2), 105-113, 2005.

[23] WEESNER, F.M. General zoological microtechniques. Williams and Wilkins company, Baltimore, Indian Edition, Scientific Book Agency, Calcutta, 1968.

[24] NISHIKIMI, M., APPAJI, N. AND YAGI, K. The occurrence of superoxide anion in the reaction of reduced phenazine methosulfate and molecular oxygen. Biochem. Biophys. Res. Commun., 46(2), 849-854, 1972.

[25] PRINS, G. K. AND LOOSE, J. A. GLUTATHIONE. Chapter 4 BiochemiCal methods in red blood cell genetics. Academic Press. N.Y.D. London, 126-129, 1969.

[26] OHKAWA, H., OHISHI, N. AND YAGI, K. Assay for lipid peroxides in animal tissues by thiobarbituric acid reaction. Anal. Biochem., 95(2), 351-358, 1979.

[27] ATTIA, S.M. Influence of resveratrol on oxidative damage in genomic DNA and apoptosis induced by cisplatin. Mutat. Res., 741(1-2), 22-31, 2012.

[28] HEINRIKSON, R.L. AND MEREDITH, S.C. Amino acid analysis by reverse-phase highperformance liquid chromatography, precolumn derivatization with phenylisothiocyanate. Anal. Biochem.,136(1), 65-74, 1984.

[29] PAGEL, P., BLOME, J. AND WOLF, H.U. High-performance liquid chromatographic separation and measurement of various biogenic compounds possibly involved in the pathomechanism of Parkinson's disease. J. Chromatogr. B. Biomed. Sci. Appl., 746(2), 297-304, 2000.

[30] PARKER, F. AND PETERSON, N.F. Quantitative analysis of phospholipids and phospholipid fatty acids from silica gel thin-layer chromatograms. J. Lipid Res., 6, 455-460, 1965. 
[31] SCANCAR, J., MILACIC, R., BENEDIK, M. AND BUKOVEC, P. Determination of trace elements and calcium in bone of the human iliac crest by atomic absorption spectrometry. Clin. Chim. Acta., 293(1-2), 187-197, 2000.

[32] RAHMAN, S.M., VAN DAM, A.M., SCHULTZBERG, M. AND CRISBY, M. High cholesterol diet results in increased expression of interleukin- 6 and caspase-1 in the brain of apolipoprotein $\mathrm{E}$ knockout and wild type mice. J. Neuroimmunol., 169(1-2), 59-67, 2005.

[33] YI, C.X., AL-MASSADI, O., DONELAN, E., LEHTI, M., WEBER, J., RESS, C., TRIVEDI, C., MÜLLER, T.D., WOODS, S.C. AND HOFMANN, S.M. Exercise protects against high-fat dietinduced hypothalamic inflammation. Physiol. Behav., 106(4), 485-490, 2012.

[34] ROHN, T.T. AND HEAD, E. Caspases as therapeutic targets in Alzheimer's disease, is it time to "cut" to the chase?. Int. J. Clin. Exp. Pathol., 2(2), 108-118, 2009.

[35] D'AMELIO, M., CAVALlUCCI, V., MIDDEI, S., MARCHETTI, C., PACIONI, S., FERRI, A., DIAMANTINI, AND ET AL Caspase-3 triggers early synaptic dysfunction in a mouse model of Alzheimer's disease. Nat. Neurosci.,14(1), 69-76, 2011.

[36] KITAYAMA, J., FARACI, F.M., LENTZ, S.R. AND HEISTAD, D.D. Cerebral vascular dysfunction during hypercholesterolemia. Stroke, 38(7), 2136-2141, 2007.

[37] AYTAN, N., JUNG, T., TAMTÜRK, F., GRUNE, T. AND KARTAL-OZER, N. Oxidative stress related changes in the brain of hypercholesterolemic rabbits. Biofactors, 33(3), 225-236, 2008.

[38] REISI, P., DASHTI, G.R., SHABRANG, M. AND RASHIDI, B. The effect of vitamin E on neuronal apoptosis in hippocampal dentate gyrus in rabbits fed with high-cholesterol diets. Adv. Biomed. Res., 3, 42, 2014.

[39] CHEIGNON, C., TOMAS, M., BONNEFONT-ROUSSElOT, D., FALlER, P., HUREAU, C. AND COLLIN, F. Oxidative stress and the amyloid beta peptide in Alzheimer's disease. Redox. Biol.,14, 450-464, 2018.

[40] MOOS, T. AND MORGAN, E.H. Transferrin and transferrin receptor function in brain barrier systems. Cell Mol. Neurobiol., 20, 77-95, 2000.

[41] HERRMANN, W. AND OBEID, R. Homocysteine, a biomarker in neurodegenerative diseases. Clin. Chem. Lab. Med., 49(3), 435-441, 2011.

[42] PAUl, R., CHOUDHURY, A., CHANDRA BORUAH, D., DEVI, R., BHATTACHARYA, P., CHOUDHURY, M.D. AND BORAH, A. Hypercholesterolemia causes psychomotor abnormalities in mice and alterations in cortico-striatal biogenic amine neurotransmitters, Relevance to Parkinson's disease. Neurochem. Int.,108, 15-26, 2017.

[43] SEO, D., PATRICK, C. AND KENNEALY, P.J. Role of Serotonin and Dopamine System Interactions in the Neurobiology of Impulsive Aggression and its Comorbidity with other Clinical Disorders. Aggress Violent Behav.,13(5), 383-395, 2008.

[44] SCHWARTZ-BLOOM, R.D. AND SAH, R. gamma-Aminobutyric acid(A) neurotransmission and cerebral ischemia. J. Neurochem.,77(2), 353-371, 2001.

[45] GUYOT, L.L., DIAZ, F.G., O'REGAN, M.H., SONG, D. AND PHILLIS, J.W. The effect of streptozotocin-induced diabetes on the release of excitotoxic and other amino acids from the ischemic rat cerebral cortex. Neurosurgery, 48(2), 385-390, 2001.

[46] CHOI, J., YIN, T., SHINOZAKI, K., LAMPE, J.W., STEVENS, J.F., BECKER, L.B. AND KIM, J. Comprehensive analysis of phospholipids in the brain, heart, kidney, and liver: brain phospholipids are least enriched with polyunsaturated fatty acids. Mol. Cell Biochem., 442(1-2), 187-201, 2018.

[47] KOSICEK, M. AND HECIMOVIC, S. Phospholipids and Alzheimer's disease: alterations, mechanisms and potential biomarkers. Int. J. Mol. Sci., 14(1), 1310-1322, 2013. 
[48] MÜLlER, C.P., REICHEL, M., MÜHLE, C., RHEIN, C., GULBINS, E. AND KORNHUBER, J. Brain membrane lipids in major depression and anxiety disorders. Biochim. Biophys. Acta., 1851(8), 1052-1065, 2015.

[49] GUAN, Z., WANG, Y., CAIRNS, N.J., LANTOS, P.L., DALLNER, G. AND SINDELAR, P.J. Decrease and structural modifications of phosphatidylethanolamine plasmalogen in the brain with Alzheimer disease. J. Neuropathol. Exp. Neurol., 58 (7), 740-747, 1999.

[50] PAKIET, A., JAKUBIAK, A., CZUMAJ, A., SLEDZINSKI, T. AND MIKA, A. The effect of western diet on mice brain lipid composition. Nutr. Metab (Lond)., 16 (81), 2019.

[51] REFOLO, L.M., MALESTER, B., LAFRANCOIS, J., BRYANT-THOMAS, T., WANG, R., TINT, G.S., SAMBAMURTI, K., DUFF, K. AND PAPPOLLA, M.A. Hypercholesterolemia accelerates the Alzheimer's amyloid pathology in a transgenic mouse model. Neurobiol. Dis., 7(4), 321-331, 2000.

[52] ULLRICH, C., PIRCHL, M. AND HUMPEL, C. Hypercholesterolemia in rats impairs the cholinergic system and leads to memory deficits. Mol. Cell Neurosci., 45(4), 408-417, 2010.

[53] WOOD, W.G., LI, L., MÜLLER, W.E., ECKERT, G.P. Cholesterol as a Causative Factor in Alzheimer Disease, A Debatable Hypothesis. J. Neurochem., 129(4), 559-572, 2014.

[54] ABRAMOV, A.Y., IONOV, M., PAVLOV, E. AND DUCHEN, M.R. Membrane cholesterol content plays a key role in the neurotoxicity of $\beta$-amyloid, implications for Alzheimer's disease. Aging Cell, 10(4), 595-603, 2011.

[55] UMEDA, T., TOMIYAMA, T., KITAJIMA, E., IDOMOTO, T., NOMURA, S., LAMBERT, M.P., KLEIN, W.L. AND MORI, H. Hypercholesterolemia accelerates intraneuronal accumulation of $A \beta$ oligomers resulting in memory impairment in Alzheimer's disease model mice. Life Sci., 91(23-24), 1169-1176, 2012.

[56] KALAYCI, R., KAYA, M., UZUN, H., BILGIC, B., AHISHALI, B., ARICAN, N., ELMAS, I. AND KÜÇÜK, M. Influence of hypercholesterolemia and hypertension on the integrity of the blood-brain barrier in rats. Int. J. Neurosci., 119(10), 1881-1904, 2009.

[57] SHIE, F.S., JIN, L.W., COOK, D.G., LEVERENZ, J.B. AND LEBOEUF, R.C. Diet-induced hypercholesterolemia enhances brain A beta accumulation in transgenic mice. Neuroreport, 13(4), 455-459, 2002.

[58] BEHALL, K.M., SCHOLFIELD, D.J. AND HALLFRISCH, J. DIETS containing barley significantly reduce lipids in mildly hypercholesterolemic men and women. Am. J. Clin. Nutr., 80(5), 1185-1193, 2004.

[59] ALU'DATT, M.H., RABABAH, T., EREIFEJ, K., ALli, I., ALRABABAH, M.A., ALMAJWAL, A., MASADEH, N. AND ALHAMAD, M.N. Effects of barley flour and barley protein isolate on chemical, functional, nutritional and biological properties of Pita bread. Food Hydrocolloids, 26(1), 135-143, 2012.

[60] SULLIVAN, P., ARENDT, E. AND GALLAGHER, E. The increasing use of barley and barley by-products in the production of healthier baked goods. Trends in Food Science and Technology, 29(2), 124-134, 2013.

[61] SHIMIZU, C., WAKITA, Y., KIHARA, M., KOBAYASHI, N., TSUCHIYA, Y. AND NABESHIMA, T. Association of lifelong intake of barley diet with healthy aging, Changes in physical and cognitive functions and intestinal microbiome in senescence-accelerated mouseprone 8 (SAMP8). Nutrients.,11(8), 1770, 2019.

[62] BAWAZIR, A.E. Investigations on the chronic effect of Talbina (Barly Water) on hormone (cortisol and testosterone), reproductive system and some neurotransmitter contents in different brain areas of male albino rats. Am-Eu. J. Sci. Res., 5 (2), 134-142, 2010. 